\title{
Prevención del cáncer de pene
}

\author{
Peyrí Rey E.
}

Servicio de Urología. Clinica Delfos. Barcelona.

Actas Urol Esp. 2008;32(4):470

$\mathrm{T}$ ras visualizar la campaña nacional para combatir el cáncer de pene, que patrocina la Sociedad Brasileña de Urología (Fig. 1), debido al aumento del $10 \%$ de casos en Brasil, ya que piensan que con dicha campaña podrían disminuir el número de 3.000 pacientes que la padecen allí, creo que podríamos aprovechar algunos conceptos de dicha campaña a pesar que el cáncer de pene, es un tumor poco frecuente en nuestro país $10,7 \%$ de todos los tumores malignos en el varón).

Dicha campaña recomienda eliminar los factores irritativos: 1-lavar el pene diariamente, principalmente después de relaciones sexuales o masturbación. 2-enseñar al niño a realizar la higiene diaria del pene. 3-realizar autoexamen mensualmente. 4realizar un control anual por el urólogo (yo añadiría aprovechar el control de la próstata, para preguntar por alguna anomalía en el pene).
La prevención de los factores de riesgo incluye preferentemente en nuestro país el control de la infección por el virus del papiloma humano, teniendo en cuenta que es una infección en aumento (profilaxis de la misma). No existe entre los urólogos y si entre los ginecólogos, el saber valorar el potencial cancerígeno de esta infección (30-50\% de los carcinomas de pene, presentan el HVP 16-18).

Otros factores de riesgo en la neoplasia de pene, es sobre todo la fimosis, la balanopostitis crónica, liquen escleroso y atrófico, la inflamación crónica, el tabaco (relación directa estudiada), el PUVA (ultravioletas) y los tratamientos con psoralenes.

Correspondencia autor: Dr. E. Peyrí Rey

Servicio de Urología. Clínica Delfos

Avda. Hospital Militar, 151 - 08023 Barcelona. Tel.: 932545000

E-mail autor: 7956epr@comb.es

Información artículo: Imágenes en Urología

Trabajo recibido: julio 2007

Trabajo aceptado: agosto 2007

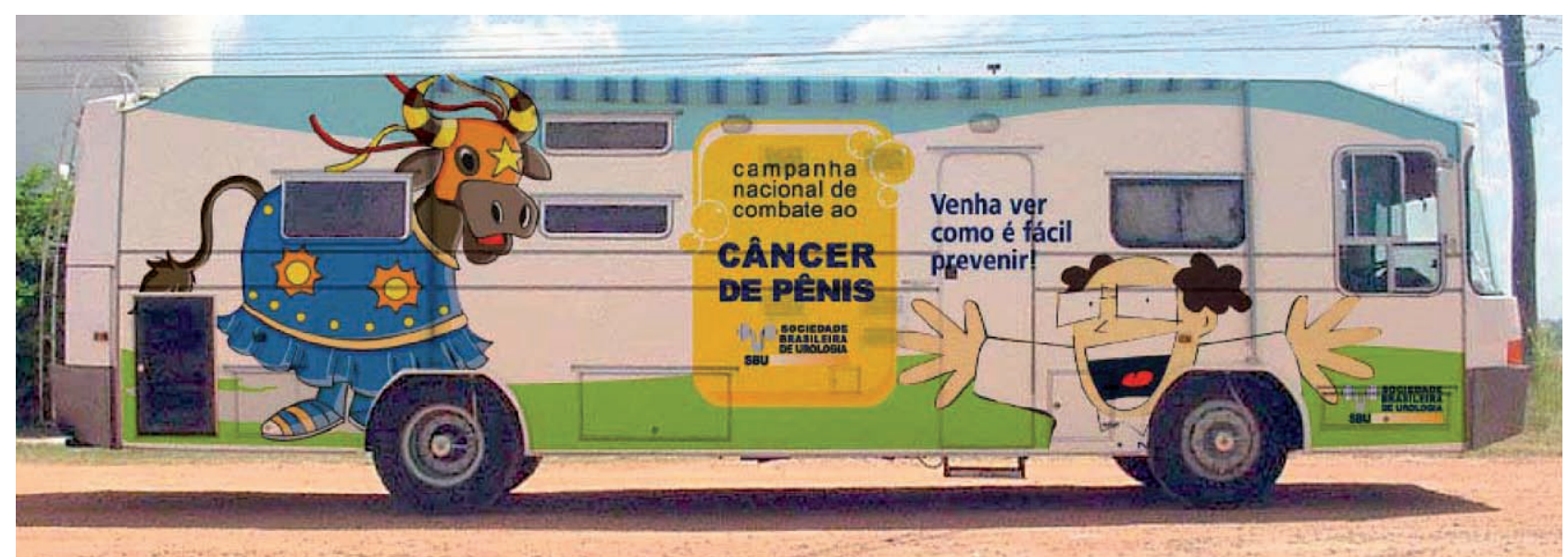

FIGURA 1 